\title{
Knowledge of first aid in road traffic accidents among drivers from the Staszów County
}

\author{
Jolanta Karyś ${ }_{\text {ABCDEFG }}$,Dorota Rębak ${ }_{\text {ABCDEFG }}$,Tomasz Karyśs ${ }_{\text {ABCDEFG }}$, Bogumiła Kowalczyk-Sroka ${ }_{\text {ABCDEFG' }}$, \\ Mariusz Maćkowski ${ }_{\text {ABCDEFG }}$ \\ ${ }^{1}$ Higher School of Economics, Law and Medical Sciences in Kielce, Poland \\ ${ }^{2}$ Faculty of Health Sciences, Jan Kochanowski University in Kielce, Poland \\ ${ }^{3}$ Marschal `s Office, Świetokrzyskie Province, Kielce, Poland
}

\begin{abstract}
Introduction. Considering the extent and consequences of road traffic accidents, drivers should know the principles of first aid.

Aim. The aim of the study was to determine the scope of knowledge concerning principles of first aid provided in road traffic accidents among drivers of the Staszów County.

Material and methods. The study encompassed 80 respondents, active drivers, mainly workers of state institutions. A diagnostic survey was carried out based on the author's questionnaire.

Results. The number of individuals capable of taking proper action aimed at protecting basic vital functions was found to be too low; 1/10th respondent would not administer any life- or health- saving first aid. The lack of knowledge regarding the ratio of chest compressions to rescue breaths was observed in $43.75 \%$ of respondents while the proper depth of compressions during cardiac massage was known to $11.25 \%$ of respondents. Additionally, not all participants of road traffic knew alarm phone numbers and were aware of a legal obligation to administer first aid to accident victims.

First aid courses expand the knowledge of pre-professional medical rescue activities.

Conclusions.

1. Only a few drivers are prepared to administer first aid on the scene. A large proportion does not know the current guidelines of the European Resuscitation Council.

2. Effectiveness of first aid courses is low; therefore, the number of practical classes should be increased, so that each participant who completed the course could deliver proper first aid at the scene of a road traffic accident. Cyclic participation of drivers in first aid courses should be considered.

3. Besides driving tests, future drivers should take exams concerning rescue procedures at the scene of accident.
\end{abstract}

Key words: first aid, road traffic accidents, resuscitation

\section{Introduction}

Road traffic accidents are a serious social problem. In Poland, traffic fatalities constitute about $20 \%$ of all deaths, which ranks us among the worst countries in Europe. Participants of road traffic are at risk of accidents; therefore, each driver should know how to administer first aid to minimize health consequences of road traffic accidents, if need be. The extent of this phenomenon necessitates mastering the principles of first aid, particularly among drivers.

In road traffic accidents, it is necessary to undertake prompt rescue activities to restore basic vital parameters of victims. The time to take action restoring basic vital functions is extremely short, i.e. 4-5 minutes. After this period, irreversible brain changes caused by hypoxia develop [1]. In such a short time, professional medical assistance is unlikely to get to the scene. The studies performed in the European countries reveal that only $10 \%$ of victims have a chance to receive professional medical help within 10 minutes after cardiac arrest $[1,2]$. Therefore, it is essential that witnesses or those involved in accidents know how to administer first aid.

First aid involves simple rescue procedures aimed at maintaining basic vital parameters until paramedics arrive. According to the statutory definition, the activities in question are a set of interventions to rescue individuals in emergency cases, performed by those present at the scene, inc- 
luding the use of medical and therapeutic products available on the market [3]. An emergency is any case in which symptoms of health deterioration develop suddenly or in a predictable short time and are likely to result in severe impairment of body functions, damage to the body or loss of life; therefore, immediate rescue activities and treatment are required [3].

Proper first aid activities administered by accident witnesses and calling for paramedics are decisive for the future of a victim. The system of life-saving services worldwide is based on the concept of ,a rescue chain” [1]. It should be strongly emphasized that the first chain links determine the fate of victims.

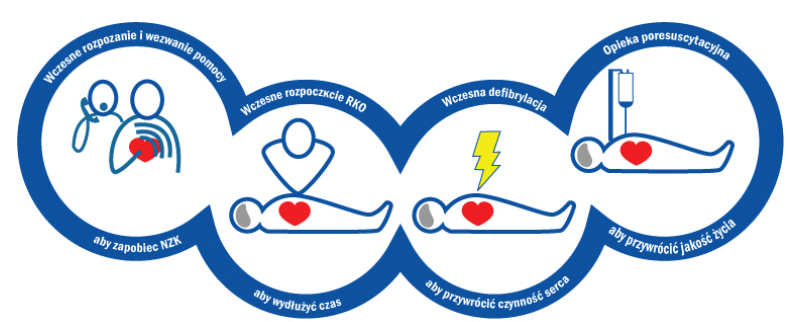

Fig. 1. A chain of survival [4]

Na rycinie - Early diagnosis and calling for help to prevent sudden circulatory arrest, Early initiation of CPR to prolong time, Early defibrillation to restore the cardiac function, Post -resuscitation care to restore the quality of life

The factor directly determining the survival of patients is a time period between sustaining injuries and provision of specialist care (most commonly at the surgical ward), called "a golden hour" [1].

The administration of first aid is a moral and legal obligation of a witness, participant or perpetrator of an incident once life or health of a victim is threatened and until the moment of death or abatement of danger $[1,5,6]$. The driver witnessing the road traffic accident or involved in it is obliged to provide victims with first aid and to call for paramedics and Police. If calling for the services mentioned above requires walking away from the accident scene, the driver is obliged to return to the scene immediately after $[7,8]$. In cases where first aid is not administered, the law provides criminal sanctions $[9,10]$.

\section{AIM}

The aim of the study was to determine the scope of knowledge concerning first aid administration in road traffic accidents by active drivers of the Staszów County (Świętokrzyskie Province).

\section{MATERIAL AND METHODS}

A diagnostic survey was carried out using the authors' questionnaire. The questionnaire contained 24 closed questions with disjunctive cafeteria. The answers included the register of necessary independent variables (including socio-demographic data) and factual questions regarding the respondents' knowledge of first aid administration in road traffic accidents.

The questionnaire study was conducted in December 2012 and January 2014 among 80 professional and non-professional drivers, mainly employed in the state institutions of the Staszów County ( Świetokrzyskie Province).

The study encompassed 45 women (56\%) and 35 men (44\%). Individuals aged $26-36$ years constituted the largest group (35\%), followed by the group of respondents above the age of 45 years (31\%). The remaining respondents were in the age ranges of $18-25$ years $(20 \%)$ and $36-45$ years (14\%). The majority of respondents lived in towns - $52(65 \%)$, the remaining ones were from the country -28 (35\%). The largest group had higher education 47 (58.75\%); 21 (26.25\%) had secondary education while the remaining 12 individuals (15\%) had vocational education. Professional drivers constituted $12.5 \%$ (10 individuals) whereas non-professional drivers $-87.5 \%$ ( 70 ) of the study group.

The knowledge of first aid principles was analyse in all drivers in total (see tables) and according to participation in first aid courses, length of possessing driving license, age of drivers and whether they are professionals

\section{RESULTS}

Table. 1. Legal obligation to provide first aid in Poland assessed by respondents

\begin{tabular}{|c|c|c|}
\hline $\begin{array}{c}\text { Legal obligation to } \\
\text { provide first aid }\end{array}$ & $\begin{array}{c}\text { Number of re- } \\
\text { sponses }\end{array}$ & $\begin{array}{c}\text { Percentage of re- } \\
\text { spondents }\end{array}$ \\
\hline $\begin{array}{c}\text { Only qualified me- } \\
\text { dical personnel }\end{array}$ & 0 & 0 \\
\hline $\begin{array}{c}\text { Individuals after } \\
\text { first aid courses }\end{array}$ & 10 & 12.5 \\
\hline $\begin{array}{c}\text { Any witness of an } \\
\text { incident }\end{array}$ & 68 & 2.5 \\
\hline $\begin{array}{c}\text { It is not legally re- } \\
\text { gulated }\end{array}$ & 2 & 100 \\
\hline Total & 80 & 85 \\
\hline
\end{tabular}


The majority of respondents (85\%) were aware of a legal obligation to administer first aid by any accident fitness; $12.5 \%$ stated that first aid should be delivered only by individuals who completed appropriate courses and $2.5 \%$ believed that those issues are not legally regulated.

Of the entire group of drivers, $78.75 \%$ knew the emergency phone number.

Table 2. The witness reaction to the accident

\begin{tabular}{|l|l|l|}
\hline Witness reaction & $\begin{array}{l}\text { Number of an- } \\
\text { swers }\end{array}$ & $\begin{array}{l}\text { Percentage of } \\
\text { respondents }\end{array}$ \\
\hline $\begin{array}{l}\text { I will try to help } \\
\text { victims at all } \\
\text { coasts as their } \\
\text { health and life are } \\
\text { essential }\end{array}$ & 19 & 23.75 \\
\hline $\begin{array}{l}\text { I will pretend that } \\
\text { I have not seen } \\
\text { anything and will } \\
\text { driver further }\end{array}$ & 2 & 2.5 \\
\hline $\begin{array}{l}\text { I will check } \\
\text { whether the } \\
\text { accident scene is } \\
\text { safe; if so, I will } \\
\text { administer first } \\
\text { aid to victims }\end{array}$ & 53 & 66.25 \\
\hline $\begin{array}{l}\text { I will not touch } \\
\text { the victims as my } \\
\text { interventions can } \\
\text { deteriorate their } \\
\text { health }\end{array}$ & 6 & 7.5 \\
\hline Total & 80 & 100 \\
\hline
\end{tabular}

In the study population, $66.2 \%$ of drivers would react appropriately (as witnesses) to the road traffic accident by checking whether the place of accident is safe and subsequently administering first aid to victims. Nineteen individuals $(23.75 \%)$ declared they would provide casualties with first aid while the remaining $7.5 \%$ would not administer any help in fear of worsening their health and $2.5 \%$ would ignore the accident, i.e. one/tenth of individuals would not deliver any life-or health-saving assistance.

The analysis of results demonstrates that 62 respondents $(77.5 \%)$ know that the victim should be taken out of the car when cardio-pulmonary resuscitation is necessary or the victim is in vehicle-associated danger. According to the remaining 18 respondents $(22.5 \%)$, victims should always be removed from vehicles.

Among 80 respondents, 44 drivers (55\%) would be able to assess properly the victim's condition, i.e. by approaching the victim from the front, grip- ping them by the shoulders and gently shaking the body, loudly and clearly ask the questions such as "Do you hear me?", " How do you feel?", "Do you know what happened?". Two respondents would check whether the victim has the eyes open, $13.75 \%$ - the reaction to slapping the face; almost every third $(28.7 \%)$ stated that none of the suggested answers was proper.

Half of respondents (50\%) aptly indicated that to restore airways, the victim 's head should be tilted backwards and the maxilla elevated; $31.25 \%$ said that a safe position should be provided, $10 \%$ would place the folded blanket under the neck and $8.75 \%$ would attempt to open the victim's mouth.

According to the findings, $36.25 \%$ of respondents knew that in order to check the victim's respiration, the patency of airway should be restored; the rescuers should observe whether the chest elevates (for 10 seconds), feeling the victim's breath on our cheek and hearing his breathing. A slightly lower percentage $(40 \%)$ stated that it would be proper to put a mirror against the victim's mouth and observe any signs of breathing; $12.5 \%$ would observe the chest movements for one minute and $11.25 \%$ for half a minute.

Moreover, every third respondent (33.75\%) knew the proper number of breaths a minute for adults, about $1 / 3$ underestimated and over 1.3 overestimated this number.

The proper ratio of chest compressions to rescue breaths (30:2) was known by 45 respondents $(56.25 \%$ ); $20 \%$ chose $15: 1,13.75 \%-15: 2$, and $10 \%-30: 5$.

The proper depth ( at least 5 , not exceeding 6 $\mathrm{cm}$ ) of chest compressions during heart massage was given by $11.25 \%$ of respondents. All the remaining ones suggested more shallow compressions: $33.75 \%-2$ to $3 \mathrm{~cm}$, the same percentage -4 to $5 \mathrm{~cm}$, the remaining $21.25 \%-3$ to $4 \mathrm{~cm}$.

The moment to start cardio-pulmonary resuscitation (when the victim does not breathe) was aptly defined by $22.5 \%$ of drivers. The majority of respondents $(62.5 \%)$ wrongly stated that CPR should be initiated in victims without breathing and pulse on the radial artery. According to $8.75 \%$ of respondents, resuscitation should be started when the victim does not react to strong pain stimuli; $6.25 \%$ believe that hen the victim is unconscious and does not react.

The vast majority (73.75\%) of respondents rightly indicated that a foreign body should be left in the wound and immobilised. Moreover, 15\% believed that the foreign body should be removed and a compression dressing placed over the wound; 
$10 \%$ would not take any actions; according to one individual (1.25\%), the foreign body should be removed and the cotton wool dressing placed over the wound.

\section{Knowledge of first aid principles according to the variables analysed}

The majority of respondents who completed first aid courses has broader knowledge on pre-professional rescue procedures, compared to those without such trainings. The percentages of proper answers to individual questions were presented in tables 3 and 4.

Table 3. Knowledge of first aid versus completed courses

\begin{tabular}{|l|l|l|}
\hline Issues & $\begin{array}{l}\text { Individuals } \\
\text { without courses }\end{array}$ & $\begin{array}{l}\text { Individuals } \\
\text { participa- } \\
\text { ting in co- } \\
\text { urses }\end{array}$ \\
\hline $\begin{array}{l}\text { Legal obligation to ad- } \\
\text { minister first aid }\end{array}$ & $73 \%$ & $92 \%$ \\
\hline $\begin{array}{l}\text { Knowing the alarm } \\
\text { number }\end{array}$ & $60 \%$ & $88 \%$ \\
\hline $\begin{array}{l}\text { Getting the victim out } \\
\text { of the car }\end{array}$ & $73.5 \%$ & $80 \%$ \\
\hline $\begin{array}{l}\text { Checking conscio- } \\
\text { usness }\end{array}$ & $46.5 \%$ & $60 \%$ \\
\hline Checking breathing & $26.5 \%$ & $42 \%$ \\
\hline $\begin{array}{l}\text { Number of chest com- } \\
\text { pressions to number of } \\
\text { rescue breaths }\end{array}$ & $46,5 \%$ & $62 \%$ \\
\hline $\begin{array}{l}\text { Depth of chest com- } \\
\text { pressions }\end{array}$ & $7 \%$ & $14 \%$ \\
\hline $\begin{array}{l}\text { Management of foreign } \\
\text { bodies }\end{array}$ & $63 \%$ & $80 \%$ \\
\hline
\end{tabular}

As far as the way of restoring the airway is concerned, the percentage of proper answers was the same in both groups, i.e. 50\%.

The moment of initiating cardiopulmonary resuscitation was more aptly defined by the individuals without first aid courses (27\%) than by those with training $(20 \%)$.

The analysis of correlations between the length of possessing driving license, age of drivers and knowledge of first aid did not show any significant differences allowing drawing explicit conclusions.

Further analysis regarding the number of professional and non-professional drivers demonstrated substantial differences in correct answers.
Table 4. Knowledge of first aid among professional and non-professional drivers

\begin{tabular}{|l|l|l|}
\hline Issues & Professional drivers & $\begin{array}{l}\text { Non-professional } \\
\text { drivers }\end{array}$ \\
\hline $\begin{array}{l}\text { Getting the vic- } \\
\text { tim out of the } \\
\text { car }\end{array}$ & $20 \%$ & $85.70 \%$ \\
\hline $\begin{array}{l}\text { Ratio of chest } \\
\text { compressions to } \\
\text { rescue breaths }\end{array}$ & $20 \%$ & $61.43 \%$ \\
\hline $\begin{array}{l}\text { Checking con- } \\
\text { sciousness }\end{array}$ & $40 \%$ & $57.14 \%$ \\
\hline $\begin{array}{l}\text { Airway restora- } \\
\text { tion }\end{array}$ & $20 \%$ & $54.29 \%$ \\
\hline
\end{tabular}

Considering the disproportions in sizes of both groups (10 professional and 70 non-professional drivers), drawing final conclusions is not justifiable. However, the differences observed imply further research in representative samples.

\section{DISCUSSION}

Analysis of the study material have demonstrated that the knowledge of drivers from the Staszów County concerning first aid is insufficient to minimise health and life-associated risks in road traffic accidents. Too few individuals can properly administer procedures to maintain basic vital functions. The time between the accident and arrival of paramedics cannot be stopped and lost minutes can result in extreme injuries to victims. It should be remembered that immediate initiation of resuscitation by witnesses increases the probability of victims' survival by three times [11]. Similar results were obtained in studies regarding drivers from Lublin [12]. Additionally, it is alarming that not all the respondents know the alarm phone numbers. Moreover, not everyone is aware that administration of first aid is a legal obligation.

First aid courses were found to broaden the knowledge of pre-professional first aid. According to the similar studies of 2012, participation in appropriate first aid trainings enables to limit the number of road traffic accident victims [13].

\section{CONCLUSIONS}

1. Only a few vehicle drivers are prepared to administer first aid at the accident scene. A large proportion of drivers do not know the current guidelines on the European Resuscitation Council.

2. The effectiveness of first aid courses is low; therefore, the number of practical classes should 
be increased so that each driver who completed the course is capable of providing proper first aid at the accident scene. Cyclic courses to improve knowledge and skills should be considered.

3. Besides driving license tests, future drivers should take exams regarding rescue interventions at the accident scene.

\section{References}

1. Goniewicz M. Pierwsza pomoc. Podręcznik dla studentów. Warszawa: PZWL; 2011.

2. Brongel L. Złota godzina. Czas życia, czas śmierci. Kraków: Krakowskie Wydawnictwo Medyczne; 2007.

3. Ustawa o Państwowym Ratownictwie Medycznym z dnia 8 września 2006 r. Dz.U., 2006, Nr 191, poz. 1410 .

4. Brzeziński T. Historia medycyny. Warszawa: PZWL; 2014.

5. Zolla A. Kodeks karny. Część szczegółowa. Komentarz t. II. Kraków: Kantor Wydawniczy Zakamycze; 2008.

6. Kuzka M, Rumian B, Maślanka M. Pielęgniarstwo ratunkowe. Warszawa: PZWL, 2012.
7. Ustawa o zmianie ustawy o Państwowym Ratownictwie Medycznym oraz niektórych innych ustaw z dnia 22 października 2010 r. Dz.U., 2010, Nr 219, poz. 1443.

8. Ustawa Prawo o ruchu drogowym z dnia 20 czerwca 1997 r. Dz.U, 1997, Nr 5, poz. 908 z późn. zm.

9. Ustawa Kodeks karny z dnia 6 czerwca 1997 r. Dz.U., 1997, Nr 88, poz. 553.

10. Marek A. Kodeks Karny. Komentarz. Warszawa: Wolters Kluwer Polska - LEX; 2010.

11. Andres J, Koster RW. Wytyczne resuscytacji 2010.Kraków: Krajowa Rada Resuscytacji; 2010.

12. Goniewicz M. Umiejętność udzielania pierwszej pomocy przez kierowców - badania ankietowe. Wiadomości lekarskie. 1998.

13. Patryn R, Żyśko M, Sobczyńska M. Analiza poziomu wiedzy i znajomości prawa dotyczącego zasad udzielania pierwszej pomocy wśród grupy aktywnych kierowców województwa lubelskiego. Medycyna Ogólna i Nauki o Zdrowiu. 2012; 18(4): 324-329.

\section{Correspondence address:}

Jolanta Karyś

Świętokrzyskie Centrum Psychiatrii, Oddział XIII Morawica ul. Spacerowa 5, 26 - 026 Morawica

Tel. 693156363

E-mail: j.a.karys@interia.pl 